\title{
Article \\ Framing Feminicides-A Quantitative Content Analysis of News Stories in Four Colombian Newspapers
}

\author{
Franziska Pröll ${ }^{1}$ and Melanie Magin ${ }^{2, *(D)}$ \\ 1 Independent Researcher, 60487 Frankfurt am Main, Germany; franziska.proell@web.de \\ 2 Department of Sociology and Political Science, Norwegian University of Science and Technology (NTNU), \\ 7491 Trondheim, Norway \\ * Correspondence: melanie.magin@ntnu.no
}

check for

updates

Citation: Pröll, Franziska, and

Melanie Magin. 2022. Framing Feminicides-A Quantitative Content Analysis of News Stories in Four Colombian Newspapers. Journalism and Media 3: 117-133. https://doi.org/10.3390/ journalmedia3010010

Academic Editor:

Andreu Casero-Ripollés

Received: 8 December 2021

Accepted: 24 January 2022

Published: 8 February 2022

Publisher's Note: MDPI stays neutral with regard to jurisdictional claims in published maps and institutional affiliations.

Copyright: () 2022 by the authors Licensee MDPI, Basel, Switzerland. This article is an open access article distributed under the terms and conditions of the Creative Commons Attribution (CC BY) license (https:/ / creativecommons.org/licenses/by/ $4.0 /)$.

\begin{abstract}
Colombia is marked by high levels of gender-based violence. In 2020, 630 women were murdered because of their gender. The number of these feminicides increased under the coronavirus lockdown that began in March 2020. Although the news media play a crucial role in shaping the public's notion of feminicides, empirical studies on the media's portrayal of feminicides in Colombia are scarce. The present study involved a quantitative content analysis of articles published in four Colombian newspapers to determine how they reported on feminicides from August 2019 to July 2020 (sample size: 139 articles, comprising 1798 paragraphs). The period under investigation allowed for a comparison of news coverage before and during the lockdown. By means of hierarchical cluster analysis, we identified four frames: "gender-based inequalities and discrimination against women", "perpetrators in front of the court", "prehistory and course of events of the feminicide", and "reactions of neighbors, eyewitnesses, and villagers to the feminicide". Our findings suggest that the four newspapers under investigation paint rather similar pictures of feminicides. We also found that the date an article was published in relation to the COVID-19 quarantine had little influence on the frequency at which the clusters appeared.
\end{abstract}

Keywords: femicide; feminicide; frames; framing; content analysis; Colombia

\section{Introduction}

Colombia is marked by high levels of gender-based violence. According to the Feminicide Observation Centre, 630 women were murdered in 2020 because of their gender (infobae 2020), compared to 571 in 2019 (Red Feminista Antimilitarista 2020a). This indicates that gender-motivated homicides increased during the coronavirus pandemic and the related lockdown in Colombia, when people were under domestic quarantine.

The intentional, gender-driven murder of a woman is called "femicide" or "feminicide". Scholars studying violence against women maintain an ongoing debate about the implications of each term (Flores 2017; UN Women 2018). Jill Radford and Diana Russell, who first coined the term "femicide", defined it as "the murder of women and girls because they are female" (Russell 2009, p. 30). Marcela Lagarde, a Mexican feminist, anthropologist, and activist, created the term "feminicide" in 2006. Her purpose was to extend the meaning of "femicide" to emphasize that these killings are not only gender-motivated but are also produced through impunity and institutional violence (Lagarde 2006). Using the term "feminicide" reflects these contextual conditions and considers the murder of women to be a result of "society's biased power structure, which maintain[s] men in dominant and privileged positions" (Saccomano 2015, p. 8). Since such structural contexts play a particularly important role in Latin America, this study employs the term "feminicide".

The most common type of feminicide in Latin America is intimate feminicide, which occurs when a woman is murdered by her (ex-)partner. Feminicide is often seen as the far end of increasing degrees of violence-ongoing verbal threats, intimidations, and physical 
or sexual abuse, finally culminating in the woman's murder. Such developments are often fostered by the fact that women are less powerful and have fewer economic resources than their partners (World Health Organization 2012). Each murder of a woman that is linked to her gender role, to the corresponding life and realization of opportunities, can be considered a "feminicide", which applies, for example, to many murders that take place within partnerships or other personal relationships. Such murders of females are distinguished from those that are not related to gender, such as when a woman is killed during a bank robbery because she was simply in the wrong place at the wrong time.

News media play a crucial role in shaping the public's notion of feminicides (Lagos Lira 2008; Taylor 2009). With their selection and coverage of current topics and events, they shape recipients' opinions, attitudes, and behavior (Sánchez Meza 2016; Menéndez Menéndez 2014; Taylor 2009). Furthermore, news content can serve as an indicator of a society's treatment of women, as well as the societal relevance and evaluation of feminicides (Carballido González 2010). Therefore, news media can contribute to initiating changes in criminal law (Branch 2019) and can support a society's elimination of gender discrimination (Tiscareño-García 2020; Taylor 2009). However, the news media can also entrench existing (power) relations and contribute to solidifying the status quo, such as by individualizing feminicides as private problems and personal tragedies. Therefore, empirical investigations of news coverage on feminicides are highly relevant, particularly quantitative studies that allow for the identification of overarching patterns in the news. This is especially important for Colombia, where women are exposed to violence in specific, gender-related ways, because of, or in relation to, the armed conflict (Suarez Pinzón 2015; Wirtz et al. 2014). Such studies, however, are extremely rare. With reference to Colombia, quantitative research on the media's representation of feminicides is almost completely nonexistent, and the few qualitative studies in the literature have serious methodological deficiencies.

Our study addresses this research gap by seeking to discover the patterns that characterize the coverage of feminicide by selected Colombian daily newspapers. To that aim, we conducted a quantitative content analysis of articles published in four Colombian newspapers of different types (national vs. regional scope; broadsheet vs. tabloid). Following the methodological approach presented by Matthes and Kohring (2008) and employing a hierarchical cluster analysis, we extracted news media frames out of the material examined, which spanned a one-year period (August 2019 to July 2020). Frames that occur regularly over such a long period of time can have a lasting impact on readers' perceptions and evaluations of feminicides (Magin et al. 2013; Matthes 2014). Moreover, the period chosen allowed for a comparison of the coverage during five months under COVID-19 pandemic lockdown conditions with coverage from seven prelockdown months.

In this paper, we first describe the present situation for women in Colombia and provide an overview of the current state of research on news media coverage of violence against women, with a special focus on Latin American countries. Then, we discuss our theoretical framework and provide our research questions. After explaining our research method, we present our results and discuss their implications and limitations.

\section{The Situation for Women in Colombia}

Political violence in Colombia began in the 1940s and evolved into an armed conflict which lasted for more than fifty years (1964-2016). The main actors were the Colombian government and the armed group called the "Revolutionary Armed Forces of ColombiaPeople's Army (FARC)". The conflict formally ended in November 2016 with a peace treaty, but it continues in remote areas of the country where the state is largely absent. Different armed and paramilitary groups commit human rights violations to maintain their control over the civilian population, with gender-based violence used often as a method to control people. For example, studies have documented violations of women and girls, sexual abuse, forced or coerced prostitution, forced abortion, and feminicide (Wirtz et al. 2014; Centro Nacional de Memoria Histórica 2013, 2017). 
Regardless of the conflict, women in Colombia have fewer opportunities in life and for personal fulfillment than men (Organización Mundial de la Salud 2013). As in many other countries, women are less likely to obtain top job positions, and they earn less than men. The average gender pay gap in Colombia, using all persons employed in the private sector as a measure, has been calculated at 10.5\% (Fundación et al. 2019). Furthermore, women take on more unpaid care work, often in addition to their paid employment, which subjects them to multiple stresses. Consequently, women are confronted with a variety of risk factors that make them more vulnerable to abuse, exploitation, or violence than men. This general panorama of gender inequalities must be considered when we analyze the news coverage on feminicides in Colombian newspapers.

Even feminicides committed by individual perpetrators are promoted by certain social structures. Most perpetrators of feminicides in Colombia remain unpunished. Corruption, persistent patriarchal attitudes, the general weakness of the state, and a lack of gender sensitivity often impede the initiation of criminal proceedings inquiries. The same factors can also lead courts to impose mild sentences on perpetrators (Melgar and Belausteguigoitia 2005; Saccomano 2015; Toledo Vásquez 2009; Aída 2019).

\section{The Media Portrayal of Feminicides}

The media's portrayal of feminicides has not yet become an important subject of scientific research in Columbia, in Latin America, or beyond. The relevant studies that do exist focus on countries such as Bolivia (Suárez 2018), Chile (Neira Mellado 2013), Guatemala (England 2018; Godoy-Paiz 2012), Mexico (Gutiérrez Aldrete 2020; Jalomo 2021), Italy (Gius and Lalli 2014), and the United States (Branch 2019; Gillespie et al. 2013).

The theoretical contributions in the literature work to varying degrees with scientific theories and approaches, but are not necessarily scientifically grounded (e.g., Pereyra 2009; Rodríguez et al. 2016). Particularly striking is the lack of quantitative studies (for exceptions, see Aldrete 2020; Neira Mellado 2013). Most empirical studies-including many bachelor's and master's degree theses (Páez Benavides 2018; Vargas Bustillo 2019; Branch 2019; López Triana 2017; Suárez 2018; Neira Mellado 2013; Jalomo 2021)—employ qualitative approaches (Angélico et al. 2014; Flores 2017; Páez Benavides 2018; Gallur Santorum and Orosa 2016; Bouzerdan and Whitten-Woodring 2018; Godoy-Paiz 2012; Rodríguez 2008), such as qualitative content analyses, discourse analyses, and qualitative interviews, but often show methodological deficiencies. All of these studies consider only a small number of articles or a short period of investigation, which clearly limits their ability to identify overarching patterns in news coverage. Next, we take a closer look at previous studies conducted in various countries that we incorporated into the development of our framing analysis and that are, therefore, most relevant for the present study.

Tiscareño-García (2020) conducted a qualitative analysis of reports on feminicides published in four Mexican daily newspapers with a national scope and found that the behavior of the perpetrator was regularly excused by citing economic problems or claiming the offender had no other choice. Moreover, the analysis indicated that perpetrators were described as dealing "normally" with people other than the victim. Anger, rage, love, and jealousy were commonly mentioned as motives for the feminicides, which excuses or normalizes the crime. Furthermore, guilt was blamed on the circumstances, rather than on the perpetrator as a person, by means of situational causes such as arguments, quarrels, or fights; drugs; alcohol; and disease. In a few cases, guilt was even assigned to the victim, for example, by describing the woman as unfaithful, violent, addicted, possessive, alcoholic, dependent, or introverted or by clearly indicating that she did not support the perpetrator's wishes.

Following Taylor (2009), victims of feminicide are either directly or indirectly blamed. Direct blaming dominates, with more than half of the texts including negative language use (e.g., adjectives such as "greedy", "threatening", or "sexually promiscuous") and statements that the victim had not reported previous acts of violence or had met other men. Forms of indirect blaming, which is less common, include mentioning the physical, mental, 
or emotional health of the perpetrator or victim and his or her financial problems, as well as describing domestic violence in a way that makes the victim and perpetrator appear jointly responsible for the feminicide.

Sutherland et al. (2019) investigated victim blaming or excuses for the perpetrator in Australian daily newspapers. Every fifth article reported on gender-based violence in an event-oriented manner and described the woman's behavior as negative: she had been drinking and/or using drugs, flirted with, or gone home with the perpetrator; failed to report previous acts of violence; or had been out alone at night. An equal number of texts excused the offender's behavior by referring to love, jealousy, passion, revenge, alcohol, or drug use.

\section{Framing}

Overall, the few existing studies reveal a tendency in the news media to explain, excuse, or justify the perpetrator's person or behavior while attributing blame to the victim, which may reflect general reporting patterns. A framing analysis can help to further investigate this. Frames can be defined as "horizons of meaning" (Matthes 2014, p. 10; own translation) that emphasize certain information and perspectives while dismissing others. The process by which this occurs is called "framing". Although English-language studies often refer to framing theory, "no coherent body of theory or network of theoretical propositions" exists in the literature (Matthes 2014, p. 10; own translation). As Potthoff (2012) pointed out, authors use the frame concept differently. In our study, we follow Entman's (1993) widely used definition: "[t]o frame is to select some aspects of a perceived reality and make them more salient in a communicating text, in such a way as to promote a particular problem definition, causal interpretation, moral evaluation, and/or treatment recommendation for the item described" (52). Four frame elements are central to our framing analysis: problem definition, attribution of causes or blame, moral evaluation, and treatment recommendation.

(1) The problem definition determines (a) which part of a topic is discussed (central issue) and (b) which actors are most important. "The problem definition provides a linguistic designation of the topic, which is crucial for further understanding of the topic" (Matthes 2014, p. 11; own translation). For example, in the case of feminicides, one can discuss the legislation of a country, a concrete course of events, or the reactions of relatives of a murdered woman. The problem definition does not necessarily negatively evaluate an aspect of the topic ("a problem"), but rather factually defines the issue and highlights a subtopic.

(2) The attribution of causes or blame indicates to what (e.g., the structures, the situation, an accident) or to whom (e.g., a person, an institution) a certain outcome is traced back and if the respective cause can be assigned responsibility or guilt for the outcome. For example, the guilt for a feminicide can be attributed to the victim, the perpetrator, or the structural circumstances in a country.

(3) The moral evaluation comprises questions of legitimacy and positive and negative evaluations of the outcome. For example, feminicides can be condemned as negative.

(4) The treatment recommendation consists of suggestions for how the situation can be improved and how problems can be solved; this can include, for example, potential measures to prevent feminicides.

Traditionally, empirical framing analyses derived frames beforehand-either from previous research or from their own prior knowledge and experience-and looked for the prevalence of these predefined, complete frames in the materials (e.g., Simon and Xenos 2000). Matthes and Kohring (2008) criticized this procedure because it hinders the detection of new, additional, or different frames with which the researcher is not familiar. To avoid such pitfalls, these scholars developed an alternative, more explorative approach that understands frames as clusters of frame elements. They understand media frames as unique, empirically determinable patterns of text that are "composed of multiple elements selectively chosen by journalists and observable by recipients" (Matthes and Kohring 2004, 
p. 61). Rather than detecting only complete, predefined frames, they suggest separately coding the frame elements defined by Entman (1993) and identifying the patterns into which they combine (i.e., the frames) afterwards by means of statistical analysis. This can be interpreted as a "multi-dimensional configuration of reporting properties" (Zeller et al. 2010, p. 506), resulting in a particular way of looking at the respective reporting object. Framing can favor certain assessments of reality and push back others. It is important to note that Matthes and Kohring (2008) considered not only the presence but also the absence of an element as meaningful for a frame. An advantage of this approach is that researchers' expectations are less influential than procedures that predefine a certain number of entire frames, which makes the method more open and explorative (Matthes and Kohring 2008, p. 263).

In addition to these general advantages, the approach proposed by Matthes and Kohring (2008) seems particularly appropriate for the current study because both authors of this paper were socialized in Central Europe (Germany). We, thus, may have internalized specific perspectives on feminicides that would impede our ability to recognize the full range of frames appearing in news articles from a different geographical and cultural context.

\section{Research Questions}

In our analysis, we were first interested in the overall patterns of coverage of feminicides in Colombian newspapers. We employed a framing analysis to answer our first research question:

RQ1. What frames can be identified in the Colombian newspapers' coverage of feminicides?

Our sample included newspapers of different types, and it seems plausible that their different editorial concepts may influence their coverage on feminicides. For example, tabloid newspapers tend to focus more strongly on individual cases, while broadsheets often focus more strongly on background information and structural aspects (Magin 2019). Conceivably, this also shapes the news coverage on feminicides, but due to the thin state of research available, we formulate a research question rather than a hypothesis:

RQ2. Does the framing of feminicides differ between the four newspapers under investigation?

As noted, the number of feminicides in Colombia increased during the coronavirus lockdown, and we wondered if this was reflected in the coverage, leading to the third research question:

RQ3. Has the coronavirus lockdown affected the framing of feminicides?

\section{Methods}

To answer our research questions, we conducted a manual quantitative content analysis. Following the two-step approach developed by Matthes and Kohring (2008), we first coded a large number of frame elements separately. Second, we condensed these frame elements into overarching frames by means of a hierarchical cluster analysis.

\subsection{Sample}

Data from various countries have shown an increase in the number of feminicides on holidays and during vacations. The one-year study period (1 August 2019 to 31 July 2020) for this research accounted for such seasonal variations in the number of feminicides. Moreover, this specific period enabled us to compare coverage during five months of the lockdown due to the coronavirus pandemic with coverage from seven preceding nonquarantine months.

The sample consisted of four Colombian newspapers that were among the most read newspapers in Colombia (ACIM Colombia 2019; FECOLPER and Reporteros sin Fronteras 2015): El Tiempo and El Espectador, two liberal broadsheets of national scope with editorial departments located in Bogotá; El Colombiano, a liberal, regional newspaper published in 
Medellin, the capital of the department of Antioquia, where the number of feminicides was highest in 2019 (Red Feminista Antimilitarista 2020b); and the tabloid $Q^{\prime} H u b o$, the most popular medium in Colombia at the time (ACIM Colombia 2019)—of its 12 regional editions, we investigated the edition available in Bogotá.

We analyzed the websites of El Tiempo, El Espectador, and El Colombiano, as well as the printed version of $Q^{\prime} H u b o$, which does not offer a website but instead publishes a PDF file of its printed version online. We searched all articles published in the four newspapers during the period under investigation for the keyword "feminicide". We included only articles containing this keyword in our analysis because we assumed that readers only recognize a feminicide as such when it is so named. In other words, we considered the audience perspective when defining the selection criterion. Moreover, using other selection criteria may have added many articles to our sample that did not report on feminicides, so the coder would have had to determine if the reported act was considered a feminicide, dependent only on the information provided in the article. This would have made the selection too subjective.

While three newspapers in our sample each published a manageable number of relevant articles, in the case of El Tiempo, the number of relevant articles, at 213, exceeded our coding capacities. We therefore drew a $25 \%$ random sample from the 213 articles, which resulted in a number of articles comparable to those from the three other newspapers. Altogether, we identified 171 articles. From these, 29 articles were excluded from the analysis because the reported feminicide occurred outside of Colombia or the victim survived, and 3 were excluded because they consisted of only a single paragraph. This left us with a total sample of 139 articles (El Tiempo: $n=46$; El Espectador: $n=28$; El Colombiano: $n=45$; $Q^{\prime} H u b o: n=20$ ), comprising 1798 paragraphs. We identified frames based on paragraphs rather than on articles to elicit more differentiated results and to account for the fact that articles often contain multiple perspectives on issues (see Magin et al. 2013).

\subsection{Measurement}

On an article level, the newspaper that published the article and the publication date were coded. The latter was later recoded as pre-lockdown vs. lockdown months.

On the paragraph level, we searched each paragraph for the four frame elements. To fully cover the debate on feminicides in Colombia, we derived a high number of differentiated categories from the literature. However, to consider only frames that realistically could have a lasting influence on recipients' impressions of feminicides, we only included in the cluster analysis categories that appeared in more than $5 \%$ of the paragraphs. The framing analysis, thus, consisted of 34 categories (Table 1; the codebook with the category descriptions can be found in the supplementary material). All categories were (re-)coded into binary variables (present $=1$; not present $=0$ ) for the cluster analysis.

Problem definition. According to Matthes and Kohring (2008), the problem definition comprises (a) the central issue and (b) the most important actor(s). Both are necessary to define the central aspect of a news story and were coded separately. Up to five central issues and up to five most important actors could be coded per paragraph. A total of 15 central issues and 15 most important actors were present in more than $5 \%$ of the paragraphs (Table 1). For the cluster analysis, we recoded these 30 categories into binary variables (present/not present).

Attribution of causes or blame. Cause was defined as someone/something that causes an event, an appearance, or a condition, while blaming means that someone/something is ascribed guilt/personally accused of the feminicide, which presupposes that one could have decided differently. An actor can be ascribed guilt for the death of a woman either because that actor committed the act or because the actor did not prevent it. Both causes and blame can be ascribed to either a person or a situation. We coded for each paragraph whether a certain outcome was traced back to a person or a situation and whether the person or situation was seen as a cause or as guilty of a concrete feminicide or feminicides in general. The coding presupposed that guilt was explicitly indicated in the language of 
an article, for example, in phrases such as " $X$ is responsible for the offense" or "the crime happened because of $X^{\prime \prime}$. However, of all potential categories, only two- "perpetrator as a cause" and "perpetrator is guilty" — were mentioned in more than $5 \%$ of the paragraphs and thus included in the cluster analysis.

Table 1. Overview of categories included in the frame analysis.

\begin{tabular}{|c|c|c|}
\hline Frame Element & Categories Included in the $\mathbf{H}$ & erarchical Cluster Analysis \\
\hline $\begin{array}{l}\text { Problem } \\
\text { definition }\end{array}$ & 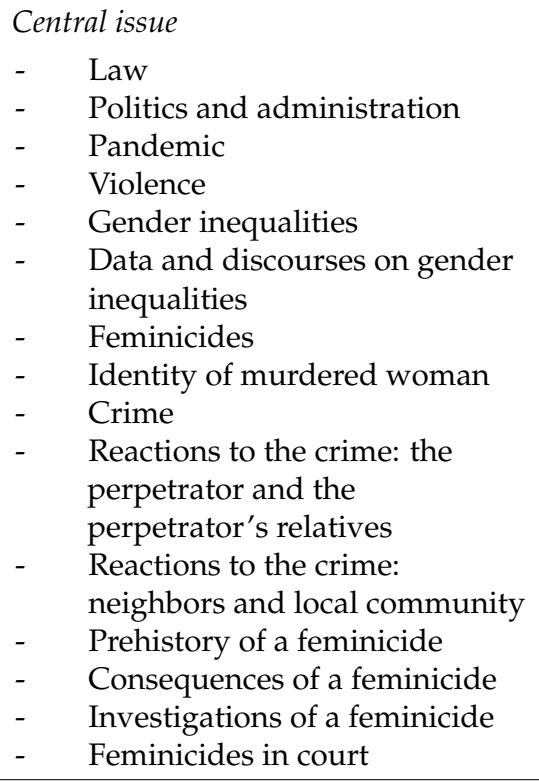 & $\begin{array}{ll}\text { Most important actor } \\
- & \text { Politicians } \\
- & \text { Authorities } \\
- & \text { Judges } \\
- & \text { Public prosecutor's office } \\
- & \text { Police } \\
- & \text { Women as a societal group } \\
& \text { Different types of professions, } \\
\text { - } & \text { Feminh as professors or doctors } \\
- & \text { Victims of feminicide } \\
- & \text { Relatives or friends of a victim } \\
\text { - } & \text { Per feminicide } \\
- & \text { Relatives or friends of a } \\
\text { - } & \text { perpetrator of feminicide } \\
- & \text { Perpetritnesses } \\
\text { than feminicides } \\
\text { Other societal groups }\end{array}$ \\
\hline $\begin{array}{l}\text { Attribution of } \\
\text { causes or blame }\end{array}$ & $\begin{array}{ll}- & \text { Perpetrator as a cause } \\
\text { - } & \text { Perpetrator is guilty }\end{array}$ & \\
\hline $\begin{array}{l}\text { Moral } \\
\text { evaluation }\end{array}$ & Negative evaluation & \\
\hline $\begin{array}{l}\text { Treatment rec- } \\
\text { ommendation }\end{array}$ & Treatment recommendation & \\
\hline $\begin{array}{l}\text { All } 34 \text { categories } \\
\text { before conductin }\end{array}$ & $\begin{array}{l}\text { e coded as or recoded into binary cate } \\
\text { e cluster analysis. }\end{array}$ & ories $($ present $=1 /$ not present $=0)$ \\
\hline
\end{tabular}

Moral evaluation. For moral evaluation, we coded whether a feminicide was evaluated as negative, positive, or neutral. Up to five evaluations of a feminicide and up to five levels could be coded per paragraph. The evaluation could be found in expressions of varying lengths, from single words (e.g., "unfortunately") up to several sentences. Terms such as "pain", "anger", "indignation", "rejection", "horror", "brutal", and "tragedy" were considered indicators of negative evaluations, but statements such as those noting that a feminicide "moves" or "triggers reactions" were not. More than 5\% of the paragraphs contained negative evaluations of feminicides, while none containing any positive evaluations of feminicides were found. Moral evaluations were, therefore, recoded into "negative evaluation present $(=1) /$ not present $(=0)$ " to be included in the cluster analysis.

Treatment recommendation. We coded if the text stated that certain measures should be taken to address the problem of feminicides. The six possible suggestions of treatment recommendations defined in the codebook appeared only rarely in the paragraphs. To reach the minimum of $5 \%$ of paragraphs for the cluster analysis, we recoded them into "treatment recommendation present $(=1) /$ not present $(=0)$ ".

\subsection{Reliability}

Coding was performed by one coder as part of her master's thesis work. A total of 21 articles (15\% of the sample) were coded twice to test for intracoder reliability. We used 
Brennan-Prediger's kappa because it is chance-corrected and more robust than Krippendorff's alpha regarding variables with a skewed distribution (Quarfoot and Levine 2016). The results indicated sufficient-to-high reliability for almost all categories (month: 1.00; newspaper: 0.937 ; central issue: 0.874 ; most important actors: 0.883 ; perpetrator as cause: 0.818; perpetrator is guilty: 0.590; moral evaluation: 0.742; treatment recommendation: $0.934)$. The reliability for "perpetrator is guilty" was lower than desirable, but nevertheless shows that agreement was clearly larger than random. Therefore, we included this variable in the cluster analysis because we considered it important to have this aspect represented for theoretical reasons.

\section{Findings}

\subsection{Identification of Frames (RQ1)}

RQ1 aimed to uncover frames in the Colombian newspapers' coverage of feminicides. To answer this question, we carried out a hierarchical cluster analysis (Ward method), an evaluation strategy appropriate for identifying suitable cluster solutions. The so-called elbow criterion was used to determine the number of clusters (Matthes and Kohring 2008). Each cluster followed the principle of homogeneity or internal cohesion: articles within a cluster are as similar as possible, while articles in different clusters differ as much as possible (Zeller et al. 2010). The elbow criterion determined a solution of four clusters (Table 2). To describe the content of each cluster, mean values for each of the variables were compared. The closer the mean $(M)$ of a variable was to 1 , the more significant it was for a cluster. To determine the extent to which the mean values of the variables differed regarding individual frame elements, we conducted a one-factor analysis of variance (ANOVA), including post hoc tests. While the ANOVA only indicated differences between the mean values of the frame elements, post hoc tests revealed the frame elements between which these differences were significant. Due to the variance heterogeneity of the groups compared, the presentation of the results is based on a Games-Howell test. Assignment to frames was performed at the paragraph level $(n=1798)$. Table 2 presents an overview of the four frames, which are named after the central features they include.

Table 2. Frames in feminicide coverage of the four Colombian newspapers under investigation.

\begin{tabular}{|c|c|c|c|c|}
\hline & $\begin{array}{c}\text { Frame 1: } \\
\text { Gender-based inequalities } \\
\text { and discrimination against } \\
\text { women }\end{array}$ & $\begin{array}{c}\text { Frame 2: } \\
\text { Perpetrators in } \\
\text { front of the court }\end{array}$ & $\begin{array}{l}\text { Frame 3: } \\
\text { Prehistory and course of } \\
\text { events of the feminicide }\end{array}$ & $\begin{array}{c}\text { Frame 4: } \\
\text { Reactions of neighbors, } \\
\text { eyewitnesses, and villagers } \\
\text { to the feminicide }\end{array}$ \\
\hline $\begin{array}{l}\text { Problem } \\
\text { definition: Topics }\end{array}$ & $\begin{array}{c}\text { Gender inequalities and } \\
\text { discrimination against } \\
\text { women }\end{array}$ & $\begin{array}{l}\text { Court processes } \\
\text { and feminicide } \\
\text { investigations }\end{array}$ & $\begin{array}{c}\text { Procession of the } \\
\text { feminicide Prehistory of } \\
\text { the feminicide } \\
\text { Characteristics of a } \\
\text { murdered woman }\end{array}$ & Reactions to the feminicide \\
\hline $\begin{array}{l}\text { Problem } \\
\text { definition: Actors }\end{array}$ & $\begin{array}{l}\text { Women as } \\
\text { a social group }\end{array}$ & $\begin{array}{c}\text { Judges } \\
\text { Public prosecutor's } \\
\text { office } \\
\text { Perpetrators } \\
\end{array}$ & $\begin{array}{c}\text { Victims } \\
\text { Perpetrators }\end{array}$ & $\begin{array}{c}\text { Neighbors } \\
\text { Eyewitnesses } \\
\text { Police } \\
\text { Authorities } \\
\end{array}$ \\
\hline Causes & - & - & $\begin{array}{l}\text { Perpetrator } \\
\text { as cause }\end{array}$ & - \\
\hline Blame & - & Perpetrator is guilty & - & - \\
\hline Moral evaluations & - & - & - & Negative \\
\hline $\begin{array}{l}\text { Treatment recom- } \\
\text { mendations }\end{array}$ & Yes & - & - & - \\
\hline $\begin{array}{l}\text { Number of } \\
\text { paragraphs }\end{array}$ & 1029 & 386 & 365 & 18 \\
\hline $\begin{array}{l}\text { Percentage share } \\
\text { of paragraphs }\end{array}$ & 57 & 21 & 20 & 1 \\
\hline
\end{tabular}

Basis: Hierarchical cluster analysis of 34 variables that were assigned one of four frame elements. Content that is relatively meaningful for a frame is listed here $(\mathrm{N}=1789$ paragraphs in 139 articles). 
Frame 1: Gender-based inequalities and discrimination against women. The first frame is mainly characterized by three topics: gender inequalities $(M=0.25 ; S D=0.43)$, law $(M=0.19 ; S D=0.39)$, and the coronavirus pandemic $(M=0.12 ; S D=0.32)$. The most important actors in this frame, according to our analysis, were women as a social group $(M=0.24$; $S D=0.42)$, while moral evaluations were widely missing from paragraphs belonging to this first cluster. Although treatment recommendations rarely appeared in the news articles, their role in the first frame $(M=0.09 ; S D=0.35)$ was found to be significantly larger than in the other three frames: indeed, treatment recommendations appear $9 \%$ more often in the first cluster than in the other three clusters. ${ }^{1}$

Taken together, the first frame addresses gender stereotypes, gender discrimination, and gender-based violence against women. The respective paragraphs refer to existing laws in Colombia, discuss the effectiveness of those laws, and call for the actual application of laws, which in some cases is presented as a solution to the existing discrimination and use of violence. Some of the paragraphs refer to the COVID-19 pandemic and the increased risk of women becoming victims of gender-based violence associated with the pandemic.

The first frame was most commonly identified in our sample, accounting for 1029, or $57 \%$, of all paragraphs in the sample (Table 2) and was the dominant frame (meaning it was present in most paragraphs) in 79 articles (Table 3). A typical article in which the first frame dominates is entitled "Cuando una mujer dice No, quiere decir No" ("When a woman says no, she means no"), published on 22 August 2019, in El Colombiano. The article comments on gender stereotypes, noting that these stereotypes guide many men's behavior toward women. Such stereotypes include, for example, that a woman needs a strong man at her side and that a man needs to subjugate a woman to feel valuable and to protect his pride from being hurt. The article explains the social implications of such stereotypes and refers to a law that is supposed to punish those guilty of sexual harassment.

Table 3. Dominant frames per article in the four newspapers under investigation.

\begin{tabular}{|c|c|c|c|c|c|}
\hline & $\begin{array}{l}\text { El } \\
\text { Tiempo } \\
\quad(\%)\end{array}$ & $\begin{array}{l}E l \\
\text { Espectador } \\
(\%)\end{array}$ & $\begin{array}{c}\text { El } \\
\text { Colombiano } \\
(\%)\end{array}$ & $\begin{array}{c}Q_{(\%)}^{\prime H u b o} \\
(\%)\end{array}$ & $\begin{array}{c}\text { All } \\
\text { Newspapers }\end{array}$ \\
\hline $\begin{array}{l}\text { Frame 1: } \\
\text { Gender-based inequalities and } \\
\text { discrimination against women } \\
\text { ( } n=79 \text { articles) }\end{array}$ & 61 & 61 & 67 & 20 & 56 \\
\hline $\begin{array}{l}\text { Frame 2: } \\
\text { Perpetrators in front of the court } \\
(n=26)\end{array}$ & 26 & 14 & 20 & 5 & 19 \\
\hline $\begin{array}{l}\text { Frame 3: } \\
\text { Prehistory and course of events of the } \\
\text { feminicide } \\
(n=22)\end{array}$ & 11 & 14 & 2 & 60 & 16 \\
\hline $\begin{array}{l}\text { Frame } 4 \text { : } \\
\text { Reactions of neighbors, eyewitnesses, and } \\
\text { villagers to the feminicide } \\
(n=0)\end{array}$ & - & - & - & - & - \\
\hline $\begin{array}{l}\text { Balanced articles: } \\
2-3 \text { frames equally present } \\
(n=12)\end{array}$ & 2 & 11 & 11 & 15 & 9 \\
\hline Total (\%) & 100 & 100 & 100 & 100 & 100 \\
\hline Number of articles & 46 & 28 & 45 & 20 & 139 \\
\hline
\end{tabular}

Basis: Sample of articles with a length of at least two paragraphs ( $n=139$ articles).

Frame 2: Perpetrators in front of the court. The second frame pertains to court decisions that condemn perpetrators of feminicide $(M=0.64 ; S D=0.48)$. Our findings indicate that this topic was significantly more important for this frame than for the three others (between $54-64 \%$ more important). ${ }^{2}$ This frame also deals with the inquiry of feminicide $(M=0.22$; 
$S D=0.42$ ), which was significantly more important for this frame than for frames 1 and $3{ }^{3}$ while no statistically significant difference to frame 4 was revealed. Moreover, the culpability of the perpetrator was significantly more important in frame 2 than in frame $1(M=0.7 ; S D=0.46$; no significant differences from frames 3 and 4$) .{ }^{4}$ Judges $(M=0.31$; $S D=0.46)$ and public prosecutors or the National Institute of Forensic Medicine $(M=0.28$; $S D=0.45)$ were identified as significantly more important actors for the second frame compared to the other frames. ${ }^{5}$

This frame was found in the second highest number of articles in the sample, but that number was considerably less prevalent than the number of articles reflecting the first frame. This frame was found in 386 , or $21 \%$, of the paragraphs in the sample (Table 2) and was the dominant frame in 26 articles (Table 3). A typical article in which the second frame dominates is the "La apelación de la Fiscalía a la absolución a los hermanos Uribe Noguera" ("The appeal by the Prosecutor's Office against the acquittal of the Uribe Noguera brothers"), published on 17 August 2019, in El Colombiano. It describes a court hearing in which the siblings' possible complicity in a crime committed by an already convicted murderer of a female is discussed. According to the article, the siblings were suspected of deleting messages from a cell phone that would implicate their brother, Rafael Uribe Noguera, a 38-year-old man from Bogotá, whom judges found guilty of the feminicide of Yuliana Samboní. The seven-year-old girl was kidnapped, abused, and killed. Many articles in which frame 2 dominates focus on this spectacular case of feminicide.

Another case that was highly represented in articles categorized under frame 2 is that of Ilse Ojeda, a fifty-one-year-old woman who was found dead outside of Bucaramanga after her boyfriend had reported her as missing. The corresponding articles discuss the court sentence for feminicide, a possible mental illness of the perpetrator, and an agreement that the perpetrator negotiated with the prosecution to reduce his prison sentence.

Frame 3: Prehistory and course of events of the feminicide. In contrast to the second frame, which focuses on the guilt of the perpetrator, the third frame focuses on the perpetrator as the cause of a feminicide $(M=0.33 ; S D=0.47) .{ }^{6}$ Moreover, it contains information about the prehistory of the feminicide $(M=0.31 ; S D=0.46)$, the progression of the feminicide $(M=0.33 ; S D=0.47)$, and the identity of the murdered woman $(M=0.32 ; S D=0.46){ }^{7}$ Victims $(M=0.8 ; S D=0.4)^{8}$ and perpetrators $(M=0.67 ; S D=0.47)$ of feminicide ${ }^{9}$ are significantly more important actors for the third frame than for the first and second frame but not for the fourth frame. Put differently, this frame addresses how the murdered woman lived and what violence she experienced at the hands of the perpetrator.

The third frame accounts for $365(20 \%)$ of paragraphs in the sample (Table 2) and dominates in 22 articles (Table 3). A typical article in which the third frame dominates is "Doloroso adiós de Yénifer a manos de su ex" ("Painful goodbye of Yénifer because of her ex"), published on 12 May 2020, by $Q^{\prime} H u b o$. The article describes how Yénifer's ex-boyfriend, who is described as "jealous and obsessed with her", burst into her birthday party, invited her outside to talk, and shot her in the head. Shortly afterwards, the police arrested the perpetrator. The victim is described as a mother with two children and many friends.

Frame 4: Reactions of neighbors, eyewitnesses, and villagers to the feminicide. The last frame focuses on the reactions of neighbors and eyewitnesses to the feminicide $(M=1.0$; $S D=0.0) .{ }^{10}$ Of all four frames, this topic is most important for the fourth frame. ${ }^{11}$ The corresponding paragraphs describe how neighbors and eyewitnesses help a seriously injured woman and notify the police or an ambulance. They are also quoted with reactions to the crime. Accordingly, eyewitnesses $(M=0.94 ; S D=0.24)^{12}$ are the most important actors in this frame, followed by the police $(M=0.3 ; S D=0.23)^{13}$ and authorities $(M=0.28$; $S D=0.24) .{ }^{14}$ Authorities are relevant to this frame with no significant differences to the other frames, while the only statistically significant difference regarding the relevance of the police in this frame is with the second frame. ${ }^{15}$ Moreover, the fourth frame is the one in which moral evaluations are the most prevalent of all frames $(M=0.44 ; S D=0.85)$, although 
the differences were not statistically significant. More specifically, the moral evaluations consist of descriptions of the feminicide as a terrible event or a tragic individual fate or the perpetrator is evaluated negatively.

The fourth frame was found least often by far, in only 18 paragraphs (1\% of all paragraphs). It does not dominate in any article. Rather, the corresponding paragraphs are interspersed in the articles studied. Therefore, no article typical for the fourth frame can be identified. However, typical paragraphs allow neighbors, eyewitnesses, and villagers to speak and express their pain about the murder of a woman.

\subsection{Feminicide Coverage of the Four Newspapers (RQ2)}

RQ2 addressed the differences and similarities in the feminicide coverage of the four newspapers, as measured by the representation of the four frames. To answer this question, we oriented ourselves toward the dominant impression the articles were most likely to have on an average reader. Therefore, we compared the number of articles in which the four frames dominate (i.e., occur in the majority of paragraphs of the respective article). As Table 3 shows, one dominant frame was identified in most articles, while in only $9 \%$ of the articles, several frames were equally present. Most often, the overall dominant frame 1 on gender-based inequalities was also dominant in individual articles, while frames 2 and 3 were dominant an equal number of times in individual articles. The very rarely addressed frame 4 was not found to be dominant in any of the articles.

A comparison of the four newspapers, however, showed that these overall results concealed notable differences, particularly between the tabloid $Q^{\prime} H u b o$ on one hand and the broadsheet and regional newspapers on the other hand. El Tiempo, El Espectador, and El Colombiano shared a strong focus on the overall dominating frame of gender-based inequalities. Moreover, El Tiempo and El Colombiano had a certain, but clearly less dominant, focus on perpetrators in front of the court (frame 2) in common, while being less interested in the prehistory and progression of feminicides. In El Espectador, frames 2 and 3 were found to be dominant in an equal number of articles. The feminicide coverage of $Q^{\prime} H u b o$, however, reflected a clearly different profile: unsurprisingly for a tabloid, our analysis indicated that $60 \%$ of its articles focused on the prehistory and course of events of the feminicide-that is, telling the story and providing details of the feminicide, probably in a narrative manner. Compared to that, frame 1, and particularly frame 3, played subordinated roles.

\subsection{Feminicide Coverage before and during the Coronavirus Lockdown (RQ3)}

RQ3 examined whether the publication date-specifically, before or during the coronavirus lockdown-influenced feminicide coverage. We first compared the number of relevant articles during both periods before investigating the development of the frames being addressed over time.

The number of articles in the sample indicates that the growing number of feminicides in Colombia during the coronavirus lockdown was reflected in the amount of coverage feminicides received during that period. The newspapers published 61 relevant articles in the seven prelockdown months compared to 77 in the five lockdown months (not shown in a table). This corresponds to an increase from 8.7 to 15.4 relevant articles per month. An increase is visible in El Espectador (from 1.1 to 4 articles per month), El Colombiano (from 2.7 to 5.2 per month), and El Tiempo (from 3.1 to 4.8 per month), ${ }^{16}$ while in the case of $Q^{\prime} H u b o$, the average number of articles slightly decreased from 1.7 to 1.4 articles per month.

The use of different frames before and during the COVID-19 lockdown was compared on the paragraph level. The month of publication had a significant $\left(\chi^{2}(1)=58.41, p<0.001\right)$ but very weak $(\varphi=0.18)$ influence on the presence of the first frame. The same was found to be true for frame $2\left(\chi^{2}(1)=21.00, p<0.001 ; \varphi=-0.12\right)$ and frame $3\left(\chi^{2}(1)=19.31, p<0.001\right.$; $\varphi=-0.1)$. Only for the fourth frame was no correlation found since it only occurred in a few paragraphs. In other words, the portrayal of feminicides in the four newspapers did not change significantly during the lockdown compared to the prelockdown period. 


\section{Discussion}

Feminicides are a serious social problem in Colombia, fostered by the power structures in the Colombian society that place women in a worse position than men and are responsible for poorer life opportunities for women than for men. Even if feminicides are committed by individual perpetrators, they must be considered in the context of these societal power structures. Feminicides are, thus, much more than individual tragedies. The news media coverage on feminicides shapes the public's perception of the phenomenon and contributes to making the population aware of the problem. Therefore, it is important to investigate how feminicides are portrayed in the news media; however, systematic empirical studies on this subject are scarce. As one of the first quantitative content analyses on this topic, the current study contributes to closing this research gap. It investigated what frames could be identified in the feminicide coverage of four Colombian newspapers between August 2019 and July 2020 (RQ1), how the presence of these patterns differed between the four newspapers under investigation (RQ2), and whether the framing of feminicide coverage differed before and during the coronavirus lockdown (RQ3), during which the number of feminicides in Colombia increased.

A hierarchical cluster analysis revealed four frames (RQ1). By far the most frequently occurring frame was "gender inequalities and discrimination against women", which is the only one that discusses the problem more strongly from a societal perspective, including the effectiveness of laws and potential solutions to the related problems. The three other frames-"perpetrators in front of the court", "prehistory and course of events of the feminicide", and "reactions of neighbors, eyewitnesses, and villagers to the feminicide" place feminicide on a purely individual level, thus downgrading these crimes to the status of private problems and personal tragedies. This does not do justice to the complexity of this issue. These frames can be interpreted as focal points in the discourse of Colombian daily newspapers in relation to feminicide and patterns of thought that the newspapers offer their readers about feminicide. Since only a few articles were found that represented the fourth frame, the feminicide coverage of the four newspapers in the sample was mainly characterized by the first three frames mentioned. The discourse, therefore, proved to be only minimally differentiated; another notable finding is that potential solutions to the problem were rarely discussed in the sample articles.

The overall picture of a minimally differentiated media discourse on feminicides is strengthened when comparing the use of the four frames in the four newspapers under investigation (RQ2). The broadsheets El Tiempo and El Espectador and the regional newspaper El Colombiano revealed very similar patterns, with a strong focus on the overall dominating frame on gender inequalities. This fits with broadsheets typically providing more background information and putting events in a broader context (Magin 2019. In contrast, the tabloid $Q^{\prime} H u b o$, as is typical for a tabloid, individualized the problem of feminicides by mainly portraying such incidents as individual fates, while at the same time widely neglecting the structural contexts and causes. Frames that dominate in the news media are very likely to shape recipients' perspectives on a topic (Magin et al. 2013), especially if a topic is repeatedly presented using the same frames and if the frames trigger emotions (Matthes 2014). Hence, news recipients in Colombia can be presumed to have a rather stereotypical picture of feminicides, and the many recipients of $Q^{\prime} H u b o$ news, especially, may get the impression that feminicides are a purely personal problem. This is problematic because a lack of awareness of the structural background can weaken the efforts put forth to tackle the problem.

The increasing number of feminicides that occurred during the coronavirus lockdown was reflected in the increased number of articles (in all newspapers except $Q^{\prime} H u b o$ ), while the focus on certain frames in the news coverage was not significantly affected by the pandemic (RQ3).

As with any investigation, the current one has some noteworthy limitations. First, our handling of the four extracted frames (clusters) should be critically discussed. While the first frame element ("problem definition", encompassing the central issue and most 
important actors) was associated with 30 variables, the other three frame elements were associated with only one ("moral evaluation" and "treatment recommendation") or two ("attribution of causes or blame") variables each. As a result, the first frame element is more central in the four frames than the other frame elements. A potential solution would have been reweighing issues and actors to balance all elements equally. However, we decided against this procedure, following the approach of Matthes and Kohring (2008), with which we also account for the fact that issues and actors were much more visible in the coverage than attributions of causes and blame, moral evaluations, and treatment recommendations.

Moreover, an aspect that we did not investigate but that would be interesting to investigate relates to the use of certain frames by certain sources: which frames are typically used by journalists themselves and which by the sources they refer to (e.g., official sources, such as police or prosecutors, or other sources, such as family, relatives, or friends)? This would be insightful with respect to potential attempts of frame setting (Brüggemann 2014).

Furthermore, the choice of 'feminicide' as a search term for identifying relevant articles limited the analysis to those articles that already refer to and classify feminicides as such. Articles on murders against women that are not referred to as such were excluded, even though they may, in fact, be feminicides. However, we consciously opted to follow this procedure based on the premise that feminicides most likely will mainly be perceived as feminicides by recipients and the public when they are labelled as such, and only then can they shape the public's awareness of the problem. Moreover, we thus did not leave it up to the coder to decide if a reported murder was actually a feminicide or not.

Finally, we only investigated feminicide coverage in one country over a one-year period, which limits the generalizability of our results. Feminicides are a problem not only in Colombia but all over the world. The measurement instruments that we developed provide a useful tool for investigating the media portrayal of feminicides in other countries. Cross-national comparisons can show how far frames in the coverage differ or are similar between countries and what patterns dominate in the coverage. Our study can also become the starting point for long-term comparisons that investigate how media attention towards and portrayal of feminicides have developed over time, potentially reflecting real-world developments and changes in public awareness.

This study gives us the opportunity to make some recommendations for future practice in journalism when reporting on feminicides. To raise awareness of the important social dimension of feminicides, training is needed for journalists working in different positions across the field. In Colombia, workshops are already carried out by the Fundación de Feminicidios. The participants learn to recognize common gender stereotypes and to avoid revictimizing language. Such workshops are a good measure to sensitize journalists and can function as a model for other countries.

This seems the right way to consider our results. Journalists, especially those employed by news agencies, need sensitization. They often produce the first available information on an incident. Their wording can determine the view of the journalists who edit the news, for example, in the newsroom of a daily or online newspaper. If the first report already speaks of "feminicide", certain imaginations and expectations are raised by the news editor, and if they are maintained, subsequently by the reader. If possible, any report a news agency publishes on the murder of a woman should consider the prehistory of the fatal incident and should consider possible gender-related reasons. If no gender-related reasons are visible at first glance, that does not necessarily mean that the killing was not a feminicide. In this case, journalists should make it clear that it is too early to speak definitively of a crime to which gender is relevant. Such guidance might also be included into ethical guidelines of publishing houses and at a national level.

Regarding communication with the reader, we suggest that each article covering violence against women should refer to a telephone hotline or other agencies where people who are affected (for example, of violence in relationships) can get help. Our study revealed that during the period of investigation, such information on concrete possibilities for action was scarce. 
Media are central institutions of knowledge transfer and socialization that can provide important information, contribute to primary prevention against feminicide, and work toward a society without gender discrimination. This implies a certain responsibility. As the present study shows, the four Colombian daily newspapers examined do not contribute to breaking up the historically constructed dynamics that have been consolidated over the course of centuries and that lead to women having fewer opportunities in life than men. These conditions can ultimately set in motion a cycle of violence, and in extreme cases, lead to feminicide.

Supplementary Materials: Codebook available online on https:/ / www.mdpi.com/article/10.3390 /journalmedia3010010/s1.

Author Contributions: Conceptualization, F.P.; methodology, F.P.; formal analysis, F.P.; data curation, F.P.; writing—original draft preparation, F.P.; writing—review and editing, M.M.; supervision, M.M. All authors have read and agreed to the published version of the manuscript.

Funding: This research received no external funding.

Data Availability Statement: Data are available from the authors on request.

Conflicts of Interest: The authors declare no conflict of interest.

\section{Notes}

1 As variances of the groups are inhomogeneous, a Games-Howell test was used. There are significant differences $(p<0.001)$ between the first and the second frame $(0.24,95 \%-\mathrm{CI}[0.21,0.28])$, the first and the third frame $(0.24,95 \%-\mathrm{CI}[0.20,0.28])$, and the first and the fourth frame $(0.25,95 \%$-CI $[0.22,0.28])$.

$2 \mathrm{~F}(3.1794)=442.95 ; p<0.001$. The Games-Howell test showed significant differences $(p<0.001)$ between frame 2 and frame 1 : $0.62,95 \%$-CI $[0.55,0.68]$; between frame 2 and frame 3: 0.54, 95\%-CI [0.46, 0.61]; and between frame 2 and frame $4: 0.64,95 \%-C I$ $[0.58,0.70]$.

$3 \mathrm{~F}(3.1794)=35.54 ; p<0.001$. Games-Howell tests: first frame: 0.18, 95\%-CI [0.12, 0.23], $p<0.001$; third frame: $0.11,95 \%$-CI $[0.04$, $0.18], p<0.001$.

$\mathrm{F}(3.1794)=280.96 ; p<0.001$.

5 The following differences were significant: $(p<0.001)$ : judges (frame 2-frame 1): 0.30, 95\%-CI [0.23, 0.36]; judges (frame 2-frame 3): $0.28,95 \%$-CI [0.21, 0.34]; judges (frame 2-frame 4): 0.31, 95\%-CI [0.25, 0.37]. Public prosecutor (frame 2-frame 1): 0.19, 95\%-CI $[0.13,0.26]$; public prosecutor (frame 2 -frame 3): $0.14,95 \%$-CI [0.06, 0.21]; public prosecutor (frame 2-frame 4): $0.28,95 \%-C I$ [0.22, $0.34]$.

$\mathrm{F}(3.1794)=127.58 ; p<0.001$.

$\mathrm{F}(3.1794)=174.99 ; p<0.001$.

$\mathrm{F}(3.1794)=219.43 ; p<0.001$.

$\mathrm{F}(3.1794)=280.96 ; p<0.001$.

$\mathrm{F}(3.1794)=5.94$.

The comparison of mean values was 0 from frame 1 to 3 . The ANOVA could not be calculated for "Reactions of neighbors and eyewitnesses" because the square sum inside the groups was 0 .

The Games-Howell test showed the following differences for eyewitnesses: Between frame 4 and frame 1: 0.94, 95\%-CI [0.79, 1.10], $p<0.001$; between frame 4 and frame 2: 0.93, 95\%-CI [0.78, 1.09], $p<0.001$; between frame 4 and frame 3: 0.77, 95\%-CI [0.60, $0.93], p<0.001$. F $(3.1794)=236.49 ; p<0.001$.

$\mathrm{F}(3.1794)=18.03 ; p<0.001$.

$\mathrm{F}(3.1794)=11.20 ; p<0.001$.

The Games-Howell test showed the following differences for the police: Between frame 4 and frame 2: 0.37, 95\%-CI [-0.34, -0.22 ], $p<0.001$; between frame 4 and frame 1: $p=0.055$; between frame 4 and frame 3: $p=0.055$.

16 Considering that we drew a $25 \%$ random sample from El Tiempo articles that met the selection criterion, we can assume that the actual number of articles per month was four times as high.

\section{References}

ACIM Colombia, ed. 2019. Estudio General De Medios EGM. Available online: http:/ / www.acimcolombia.com/estudios/estudio-ge neral-de-medios-egm/ (accessed on 30 December 2020). 
Aída, Avella E. 2019. Datos de Feminicidio de la Fiscalía no Coinciden con los de Organizaciones: Aída Avella. El Espectador. June 5. Available online: https://www.elespectador.com/noticias/nacional/datos-de-feminicidio-de-la-fiscalia-no-coinciden-con-los -de-organizaciones-aida-avella/ (accessed on 20 January 2022).

Aldrete, Mariana Gutiérrez. 2020. The Treatment of Femicide in Media in Mexico. Ph.D. thesis, Universitat Autònoma de Barcelona, Bellaterra, Spain.

Angélico, Rocio, Violeta Dikenstein, Sabrina Fischberg, and Florencia Maffeo. 2014. El Feminicidio y la Violencia de Género en la Prensa Argentina: un Análisis de Voces, Relatos y Actores. Universitas Humanística 78: 281-303. [CrossRef]

Bouzerdan, Camelia, and Jenifer Whitten-Woodring. 2018. Killings in Context: An Analysis of the News Framing of Femicide. Human Rights Review 19: 211-28. [CrossRef]

Branch, Danielle. 2019. Femicide in the News: How Newspaper Articles Represent the Killing of Women \& Girls in Detroit and Ciudad Juárez. Undergraduate Honors thesis, Western Michigan University, Kalamazoo, MI, USA. Available online: https: / / scholarworks.wmich.edu/cgi/viewcontent.cgi?article=4159\&context=honors_theses (accessed on 19 February 2021).

Brüggemann, Michael. 2014. Between Frame Setting and Frame Sending: How Journalists Contribute to News Frames. Communication Theory 24: 61-82. [CrossRef]

Carballido González, P. C. 2010. El Proceso de Construcción de la Violencia contra las Mujeres: Medios de Comunicación y Movimiento Feminista. Una Aproximación desde la Teoría del Framing. Ph.D. dissertation, Universitat Jaume, Castellón de la Plana, Spain.

Centro Nacional de Memoria Histórica (CNMH). 2013. Basta ya! Colombia: Memorias de Guerra y Dignidad. Available online: https:/ / www.centrodememoriahistorica.gov.co/micrositios/informeGeneral/ (accessed on 19 February 2021).

Centro Nacional de Memoria Histórica (CNMH). 2017. La Guerra Inscrita en el Cuerpo. Informe Nacional de Violencia Sexual en el Conflicto Armado. Available online: http://www.centrodememoriahistorica.gov.co/descargas/informes-accesibles/guerra-ins crita-en-el-cuerpo_accesible.pdf (accessed on 19 February 2021).

England, Sarah. 2018. Writing Terror on the Bodies of Women: Media Coverage of Violence against Women in Guatemala. Lanham: Lexington.

Entman, Robert. M. 1993. Framing: Toward Clarification of a Fractured Paradigm. Journal of Communication 43: 51-58. [CrossRef]

Federación Colombiana de Periodistas (FECOLPER), and Reporteros sin Fronteras, eds. 2015. Colombia: Actividad Periodística en Riesgo. Available online: https:/ / www.reporter-ohne-grenzen.de/fileadmin/Redaktion/Downloads/Berichte/2015/150800_Activi dad_periodistica_en_riesgo_-_RSF_e_FECOLPER.pdf (accessed on 12 February 2021).

Flores, Pamela. 2017. Cubrimiento Periodístico y Visibilidad del Feminicidio en el Heraldo (Barranquilla, Colombia): Estudio de Caso. Investigación \& Desarrollo 25: 23-48. [CrossRef]

Fundación, Corona, Fundación Andi, and United States Agency for International Development (Hrsg.). 2019. Informe Nacional de Empleo Inclusivo (INEI). Available online: http: / / www.andi.com.co/Uploads/INEI.pdf (accessed on 2 February 2021).

Gallur Santorum, Santiago, and Berta García Orosa. 2016. El Estereotipo de Género como Nuevo Valor Noticia en los Periódicos Digitales en Europa. Estudios Sobre el Mensaje Periodístico 22: 287-98. [CrossRef]

Gillespie, Lane Kirkland, Tara N. Richards, Eugena Givens, and M. Dwayne Smith. 2013. Framing Deadly Domestic Violence: Why the Media's Spin Matters in Newspaper Coverage of Femicide. Violence Against Women 19: 222-45. [CrossRef]

Gius, Chiara, and Pina Lalli. 2014. 'I Loved Her so Much, but I Killed Her.' Romantic Love as a Representational Frame for Intimate Partner Femicide in Three Italian Newspapers. ESSACHESS-Journal for Communication Studies 7: 53-75.

Godoy-Paiz, Paula. 2012. Not Just 'Another Woman': Femicide and Representation in Guatemala. The Journal of Latin American and Caribbean Anthropology 17: 88-109. [CrossRef]

Gutiérrez Aldrete, Mariana. 2020. El Tratamiento del Feminicidio en Medios de Comunicación en México. Ph.D. dissertation, Universitat Autònoma Barcelona, Bellaterra, Spain. Available online: https://www.tesisenred.net/handle/10803/670554 (accessed on 20 January 2022).

“Las Mujeres en Colombia no Están Seguras: Feminicidios Aumentaron un 9\% en 2020”. 2020. infobae, December 16. Available online: https: / / www.infobae.com/america/colombia/2020/12/16/las-mujeres-en-colombia-no-estan-seguras-feminicidiosaumentaron-un-9-en-2020/ (accessed on 20 January 2022).

Jalomo, Dafne. 2021. The Portrayals of Femicide Victims in Mexican Media: A Comparison Between Newspaper Coverage and Feminist Sources. Master's thesis, University of Helsinki, Helsinki, Finland. Available online: https://helda.helsinki.fi/handle/1 0138/331310 (accessed on 20 January 2022).

Lagarde, Marcela. 2006. Del Femicidio al Feminicidio. Jardin de Freud 6: 216-25. Available online: https://revistas.unal.edu.co/index.p $\mathrm{hp} /$ jardin/article/view/8343 (accessed on 14 February 2021).

Lagos Lira, Claudia. 2008. El Feminicidio Según la Prensa Chilena: Otra Forma de Violencia contra las Mujeres. Master's thesis, Universidad de Chile, Santiago, Chile.

López Triana, Stefanny. 2017. Eres Mía y no Serás de Nadie Más. Discursos en Torno a los Feminicidios en el Periódico El Tiempo 2010-2016. Master's thesis, Universidad Nacional de Colombia, Bogotá, Colombia.

Magin, Melanie. 2019. Elite versus popular press. In The International Encyclopedia of Journalism Studies. Edited by Tim P. Vos, Folker Hanusch, Dimitra Dimitrakopoulou, Margaretha Geertsema-Sligh and Annika Sehl. Chichester: Wiley. [CrossRef]

Magin, Melanie, Stefan Geiß, and Birgit Stark. 2013. Mediale Deutungsmuster für Social Networks-Eine Framing-Analyse. In MediaPolis-Kommunikation zwischen Boulevard und Parlament. Edited by Barbara Pfetsch, Janine Greyer and Joachim Trebbe. Konstanz: UVK, pp. 187-207.

Matthes, Jörg. 2014. Framing. Baden-Baden: Nomos. 
Matthes, Jörg, and Matthias Kohring. 2004. Die Empirische Erfassung von Medien-Frames. Medien E Kommunikationswissenschaft 52: $56-75$.

Matthes, Jörg, and Matthias Kohring. 2008. The Content Analysis of Media Frames: Toward Improving Reliability and Validity. Journal of Communication 58: 258-79. [CrossRef]

Melgar, Lucía, and Marisa Belausteguigoitia. 2005. A quiénes beneficia la impunidad? Debate Feminista 32: 253-63. [CrossRef]

Menéndez Menéndez, María Isabel. 2014. Retos Periodísticos ante la Violencia de Género. El Caso de la Prensa Local en España. Comunicación y Sociedad 22: 53-77. [CrossRef]

Neira Mellado, Carola Paz. 2013. Online Newspaper Coverage of Femicide in Chile and the US. Master's thesis, University of Kansas, Lawrence, KS, USA. Available online: https://kuscholarworks.ku.edu/bitstream/handle/1808/12257/NeiraMellado_ku_0099 M_12889_DATA_1.pdf? sequence=1\&isAllowed=y (accessed on 20 January 2022).

Organización Mundial de la Salud (OMS) (Hrsg.). 2013. Femicidio. Available online: https://apps.who.int/iris/bitstream/handle/106 65/98828/WHO_RHR (accessed on 20 February 2021).

Páez Benavides, Karem Natalia. 2018. ¡Ni una menos, ni una más!: Las rutinas periodísticas sobre la violencia contra la mujer en El Tiempo y El Espectador. Bogotá: Universidad del Rosario (Tesis de Periodismo). Available online: https: / / repositorioslatinoamer icanos.uchile.cl/handle/2250/2402747 (accessed on 31 January 2022).

Pereyra, Marcelo R. 2009. El Estudio de la Violencia de Género en los Medios: Una Herramienta Teórica y Política. Question 23. Available online: https:/ / perio.unlp.edu.ar/ojs/index.php/question/article/view/811/713 (accessed on 26 January 2019).

Potthoff, Matthias. 2012. Medien-Frames und ihre Entstehung. Wiesbaden: VS Verlag für Sozialwissenschaften.

Quarfoot, David, and Richard A. Levine. 2016. How Robust are Multirater Interrater Reliability Indices to Changes in Frequency Distribution? The American Statistician 70: 373-84. [CrossRef]

Red Feminista Antimilitarista. 2020a. 571 Feminicidios en Colombia en el año 2019. Resumen Annual. March 2. Available online: http: / / observatoriofeminicidioscolombia.org/index.php/seguimiento/412-571-feminicidios-en-colombia-en-el-ano-2019 (accessed on 20 February 2021).

Red Feminista Antimilitarista. 2020b. Reporte Dinámico Feminicidios Colombia. Available online: https://www.observatoriofeminici dioscolombia.org/index.php/reportes (accessed on 20 February 2021).

Rodríguez, María Pilar. 2008. Tratamiento de la Violencia de Género en la Prensa Vasca. León: Universidad de León, Facultad de Educación. [CrossRef]

Rodríguez, María Pilar, María J. Pando-Canteli, and Miren Berasategi. 2016. Generan Estereotipos los Medios de Comunicación? Reflexión crítica para Educadores. Deusto Social Impact Briefings, 1. Bilbao: Universidad de Deusto.

Russell, Diana E. H. 2009. Femicide: Politicizing the Killing of Females. Strengthening Understanding of Femicide. Using Research to Galvanize Action and Accountability. Edited by PATH, MRC, World Health Organization and INTERCAMBIOS. pp. 26-31. Available online: https:/ / path.azureedge.net/media/documents/GVR_femicide_rpt.pdf (accessed on 13 February 2021).

Saccomano, Celeste. 2015. The Causes of Femicide in Latin America. Barcelona: Institut Barcelona D'Estudis Internacionals (IBEI), Available online: www.jstor.org/stable/resrep14204 (accessed on 8 January 2021).

Sánchez Meza, Metzeri. 2016. El Feminicidio en la Prensa Mexicana: Análisis del Relato Construido y las Implicaciones Éticas en la Práctica Periodística. Barcelona: Trabajo de Posgrado, Universitat Pompeu Fabra.

Simon, Adam, and Michael Xenos. 2000. Media Framing and Effective Public Deliberation. Political Communication 17: 613-24. [CrossRef]

Suárez, Duberthy Mercado. 2018. Representation of Femicide According to Online Newspapers in Bolivia. Master's thesis, Malmö University. Available online: https:/ / www.diva-portal.org/smash/record.jsf?pid=diva2\%3A1483896\&dswid=8416 (accessed on 4 February 2021).

Suarez Pinzón, Ivonne. 2015. Violencia de Género y Violencia Sexual del Conflicto Armado Colombiano. C E P, Revista Cambios y Permanencias 6: 173-203. Available online: https://revistas.uis.edu.co/index.php/revistacyp/article/view/7097 (accessed on 4 February 2021).

Sutherland, Georgina, Patricia Easteal, Kate Holland, and Cathy Vaughan. 2019. Mediated Representations of Violence Against Women in the Mainstream News in Australia. BMC Public Health 19: 1-8. [CrossRef]

Taylor, R. 2009. Slain and Slandered. A Content Analysis of the Portrayal of Femicide in Crime News. Homicide Studies 13: 21-49. [CrossRef]

Tiscareño-García, E. 2020. Víctimas y Victimarios de Feminicidio en el Lenguaje de la Prensa Escrita Mexicana. Revista Científica de Educomunicación 63: 51-60. [CrossRef]

Toledo Vásquez, P. 2009. Feminicidio. Mexico-City: Oficina en México del Alto Comisionado de las Naciones Unidas para los Derechos Humanos.

UN Women, ed. 2018. Analysis of Femicide/Feminicide Legislation in Latin America and the Caribbean and a Proposal for a Model Law. Available online: https:/ /lac.unwomen.org/en/digiteca/publicaciones/2018/12/analisis-legislacion-feminicidio-femicidio-m odelo-de-ley (accessed on 4 February 2021).

Vargas Bustillo, Laura Daniela. 2019. Una Valoración al Cubrimiento del Caso Rosa Elvira Cely en el Portal Web de El Tiempo 2012 (Artículo de Investigación Académica). Bogotá: Universidad del Rosario.

World Health Organization. 2012. Femicide. Understanding and Addressing Violence against Women. Available online: https: / /apps.who.int/iris/bitstream/handle/10665/77421/WHO_RHR_12.38_eng.pdf (accessed on 20 January 2022). 
Wirtz, Andrea L., Kiemanh Pham, Nancy Glass, Saskia Loochkartt, Teemar Kidane, Decssy Cuspoca, Leonard S. Rubenstein, Sonal Singh, and Alexander Vu. 2014. Gender-based violence in conflict and displacement: Qualitative findings from displaced women in Colombia. Conflict and Health 8: 1-14. [CrossRef] [PubMed]

Zeller, Frauke, Jens Wolling, and Pablo Porten-Cheé. 2010. Framing 0/1. Wie Medien über die "Digitalisierung der Gesellschaft" berichten. $M$ \& K Medien und Kommunikationswissenschaft 58: 503-24. [CrossRef] 